University of Nebraska - Lincoln

DigitalCommons@University of Nebraska - Lincoln

2009

Middlebrow Readers and Pioneer Heroines: Willa Cather's My Ántonia, Bess Streeter Aldrich's A Lantern in Her Hand, and the Popular Fiction Market

Melissa J. Homestead

University of Nebraska-Lincoln, mhomestead2@Unl.edu

Follow this and additional works at: https://digitalcommons.unl.edu/englishfacpubs

Part of the English Language and Literature Commons

Homestead, Melissa J., "Middlebrow Readers and Pioneer Heroines: Willa Cather's My Ántonia, Bess Streeter Aldrich's A Lantern in Her Hand, and the Popular Fiction Market" (2009). Faculty Publications -Department of English. 78.

https://digitalcommons.unl.edu/englishfacpubs/78

This Article is brought to you for free and open access by the English, Department of at DigitalCommons@University of Nebraska - Lincoln. It has been accepted for inclusion in Faculty Publications -- Department of English by an authorized administrator of DigitalCommons@University of Nebraska - Lincoln. 
Published, as Chapter 4, in Crisscrossing Borders in Literature of the American West, edited by Reginald Dyck and Cheli Reutter (New York: Palgrave Macmillan, 2009).

Copyright (c) 2009 Reginald Dyck and Cheli Reutter.

\title{
Middlebrow Readers and Pioneer Heroines: Willa Cather's My Ántonia, Bess Streeter Aldrich's A Lantern in Her Hand, and the Popular Fiction Market
}

\author{
Melissa Homestead
}

In 1918, Houghton Mifflin published My Ántonia, Willa Cather's fourth novel and her second to make an immigrant woman from the Nebraska prairies its heroine. A decade later, in 1928, D. Appleton \& Co. published Bess Streeter Aldrich's A Lantern in Her Hand, another novel of the pioneer era in Nebraska with a female heroine, this one a nativeborn child of Protestant Irish immigrants. Both novels have been in print continuously since. Initial sales of My Ántonia were modest, reflecting the small size of the first edition. Houghton Mifflin paid Cather royalties on sales of 3,261 copies in October 1918, a month after the novel's initial publication. ${ }^{1}$ In the first few years after 1918, annual sales hovered at just over 1,000, but then they gradually began to climb to 2,000 and above, causing the editor, Ferris Greenslet, to remark with satisfaction in 1921, “'MY ANTONIA' seems to be settling into a very long stride." Promoted more aggressively by its publisher in a literary market much expanded in a decade. Lantern's initial sales far exceeded those of Cather's novel9,000 two months after publication, 16,000 within four months (Williams, 
Letters to BSA). Sales continued to increase, so that by the early 1930s, Lantern enjoyed the unusual distinction of first appearing on bestseller lists several years after its initial publication (Peterson, Bess Streeter Aldrich 88). Thus, like My Ántonia, Lantern had a "long stride," its steadyseller status attesting to its enduring appeal to ordinary readers.

Why, then, do these two novels so seldom appear together in literary history, and why have A Lantern in Her Hand and its author received so little sustained scholarly attention? Despite one scholar's recent analysis of what she calls the "resurrection" of A Lantern in Her Hand (Knight), the novel never "died" in the first place. Outside of the prestige economy of academia, the novel remained vitally alive. As Sharon O'Brien has observed. Cather, too, found herself outside of the canon from the 1920s on, as H. L. Mencken and other elite tastemakers who had championed her work in the teens dismissed her in gendered terms as backward-looking and minor. In the twenty-first century, however, Cather's canonical status is secure. Her works are widely taught in university classrooms, and a veritable scholarly industry publishes scores of articles on her works every year.

Along with repositioning Cather in a new reading context, this essay aims to bring Aldrich and her novel into literary history (and college classrooms) by putting her work into dialogue with Cather's. I do not, however, elevate Aldrich to the status of elite artist, a move that she herself would disavow. Instead, I seek to revalue the middlebrow as a mode of authorship, circulation, and reading for the literary history of the American West and to place Ántonia and Lantern together on that oftscorned terrain. When Aldrich is taken note of in Western literary history, she receives only glancing attention after being categorized as "sentimental," a word seldom defined but seemingly associated with pandering to readers and their emotions. ${ }^{2}$ What if, instead, we take seriously the "sentiments" of the legions of ordinary, nonacademic readers who have kept both Aldrich and Cather in print? Certainly, Cather's embrace of the literary market and the tastes of ordinary readers were more tentative and covert than Aldrich's. For instance, when she wrote to Mencken in 1922, prior to the publication of One of Ours, seeking (fruitlessly, as it turned out) to avert a negative review of her World War I novel, she reminded him that "they were both enemies of a debased, popular American literature" and were "both committed to overturning Booth Tarkington platitudes and raising American literature to a higher plane" ( $\mathrm{O}^{\prime}$ Brien 114). ${ }^{3}$ Certainly, Aldrich's current critical reputation more closely resembles that of the best-selling Indiana novelist Tarkington than Cather's, and 
Cather probably would have disavowed any connection to Aldrich as she did Tarkington. Nevertheless, locating Ántonia and Lantern together in the middlebrow recovers with more precision the terms on which Cather engaged the literary market and a popular readership. It also throws new light on the deep investment of a national readership in fictional depictions of Midwestern pioneering.

Although the terms "highbrow" and "lowbrow" designating zones of culture emerged in the nineteenth century, the term "middlebrow" first emerged in the 1920s. The middlebrow resides somewhere between the easily identifiable low of mass-circulated dime novels and pulp magazines, written up to plot outlines by nameless scribes, and the edgy avant garde of modernism circulated in little magazines and books in small editions as the creative emanations of autonomous authors. Because of this "betweenness," commentators have often criticized the middle as violating the proper boundaries between commerce (low) and art (high). Nevertheless, cultural historians and literary critics have attempted in the last fifteen years to give the middlebrow its due. Rather than identify a group of texts or authors as inherently middlebrow, Joan Shelley Rubin focuses on the middlebrow as a form of circulation and its accompanying critical apparatus "aimed at making literature and other forms of 'high' culture available to a wide reading public" (xi). In her study of the Book-of-the-Month Club (BOMC), Janice Radway likewise focuses on a business enterprise designed to distribute literary texts to a growing professional managerial class as a central institution of the middlebrow. In addition, she theorizes an associated set of reading practices in which readers identify intensely and empathize with characters they feel to be "real," leading to deep absorption in the imagined world of the book (Feeling 262, 282-84). Although some critics have damned the excluded middle in literary history because of its association with women, both as authors and as readers, feminist literary historians have recently reclaimed the middle, much as an earlier generation of scholars reclaimed popular women's writing of the nineteenth century (Radway 189-216; Botshon \& Goldsmith). Focusing on the middlebrow/ as an authorial mode practiced by women writers, Jaime Harker explains that middlebrow women authors "depended, financially and artistically, on their relationship with their readers" (6). They thus avoided radical formal experimentation and did not claim alienation as a badge of artistic authenticity or attack the values of average readers. ${ }^{4}$ 
At times, Cather's aesthetic pronouncements mock the taste of average readers. In her essay "The Novel Démeumblé" (1922), for instance. Cather publicly professed scorn for the popular taste as she did privately to Mencken. Dismissing "the novel manufactured to entertain great multitudes of people" as being like consumable cheap soap, she asks rhetorically, "Does anyone pretend that if the Woolworth store windows were piled high with Tanagra figurines at ten cents, they could for a moment compete with Kewpie brides in the popular esteem?" (44). Placing herself on the side of "art" as against "amusement," she seems to turn her back on the market and most readers (44).

Despite this public posturing, she nevertheless quietly exploited middlebrow institutions, such as book clubs and mass-circulation women's magazines, as a way to reach and engage the common reader. No doubt her experience as an editor of McClure's Magazine gave her an understanding of the evolving middle zone of the market because McClure's was, as Radway explains, one of the magazines that "invented a new product - the audience's attention - and thus were absolutely crucial to the development of a nationally oriented consumer culture" ("Research Universities" 224). My Ántonia preceded the BOMC by nearly a decade, but as Mark Madigan has recently demonstrated, many more of Cather's books received the club's imprimatur than previously recognized. Shadows on the Rock (1931) and Sapphira and the Slave Girl (1940) were Cather's only books to be "main selections" of the club, but My Mortal Enemy (1926), Death Comes for the Archbishop (1927), Obscure Destinies (1932), Lucy Gayheart (1935), and even Not Under Forty (1936) (which reprinted "The Novel Démeumblé") were all designated "other new books recommended" that readers could choose if they declined to accept the main selection (Madigan 72-79). Notably, in 1929, the BOMC designated My Ántonia an "Outstanding Older Book" readers could receive instead of a main selection (Madigan 74). Selection committee member and novelist Dorothy Canfield Fisher (Cather's friend since adolescence) wrote the review in the BOMC News, telling readers that whenever she visited a public library, the "worn and shabby" appearance of copies of Ántonia testified "the lasting love of our people for that beautiful book. ... The next step should be to move it from the public library shelf to the home shelf, to see it in every American's house as part of the stuff of life," so that people can reread and "live with" the novel and "grow up to" it (Quoted in Madigan 75). Even though Cather's fiction appeared in smaller- circulation, higher-prestige magazines earlier in her career, in the 1920s and 1930s, the women's magazines presented 
Cather's fiction to large audiences of middlebrow women readers and their families. ${ }^{5}$

Cather embraced not only middlebrow circulation, but the critical apparatus that promoted books and authors to middlebrow readers. Cather's correspondence with her family, especially her brother Roscoe, suggests that she saw her family members as model general readers and demonstrates her embrace of the middlebrow critical apparatus. Henry Seidel Canby, another BOMC judge and editor of the Saturday Review of Literature, defined the "average intelligent reader" as one "who has passed through the usual formal education in literature, who reads books as well as newspapers and magazines, who, without calling himself a litterateur, would be willing to assert that he was fairly well read and reasonably fond of good reading. Your doctor, your lawyer, the president of your bank" (quoted in Radway, Feeling 296). Her brother Roscoe, a bank president in Lander and then Casper, Wyoming, fits this profile precisely. Cather delighted in reporting the critical and popular success of her works to Roscoe, sending him reviews and press notices. In 1918, self-consciously straddling the divide between approval from professional critics and common readers, she combined in her letter a report of reviews of My Ántonia with her delight at how many ordinary people, not just highbrow cultural arbiters, enjoyed the novel despite its apparent plotlessness. Among the readers whose approval she reported with pleasure was her own father, Charles Cather, a small-town mortgage agent, who professed to like My Ántonia as much as any other book he had read. In a letter reporting his second reading of Ántonia to Willa, Charles Cather characterized both Ántonia and O Pioneers! (1913) as being "like old tried \& true friends to me." As radio developed, Cather began reporting to Roscoe about radio broadcasts featuring her as a speaker or mentioning her and her works. Rubin has characterized the middlebrow critical apparatus, and particularly "book talk" on the radio, as combining critical evaluation with an awareness of the "news value" of books and authors to readers struggling to keep up with an ever-expanding print culture (42, 266-329). The critic and radio personality Alexander Woollcott is one of Rubin's central figures. In December 1933, Woollcott "toasted" Cather's birthday on the air. Delighted but perplexed because she did not know in advance, she went to the trouble of securing a transcript of the toast to send to Roscoe. Two years later, forewarned of Woollcott's intention to "serenade" her on the air, she made sure Roscoe had advance notice (Bloom) ${ }^{6}$

Cather's and Aldrich's market strategies placed their works on the same cultural terrain and made them available to the same readers, even 
if Aldrich's public embrace of the market was more overt than Cather's. In 1921, when Aldrich was a successful magazine writer but had not yet published a book, she bluntly told readers of the American Magazine, "You have to work to be a successful writer, just as you have to work to be a successful grocery-man, or to be a successful anything else" ("How I Mixed" 38). In a speech before the Nebraska Writer's Guild, she unapologetically explained, "I see no reason why art and checks should be considered oil and water ... [W] e should write like inspired artists and sell like shrewd Yankees" (Untitled). Like Cather, Aldrich placed much of her fiction in women's magazines in the 1920s and 1930s. Aldrich's "I Remember" and Cather's My Mortal Enemy both appeared in McCall's in 1926, for instance, and Aldrich's "The Day of Retaliation" and "The Runaway Judge" and Cather's "Three Women" (the magazine title of "Old Mrs. Harris") all appeared in the Ladies' Home Journal in 1932. Cather initially expressed reservations about allowing the BOMC to make Shadows on the Rock (1931) a main selection, but Aldrich and her publishers enthusiastically sought status for Lantern as either a main selection or an alternate. ${ }^{7}$ The attempt failed, but the logic of the attempt was clear in light of one of the BOMC's objectives - to get books to readers who lived outside of major metropolitan areas and had limited access to well-stocked bookstores (Radway, Feeling 190-91).

Aldrich's embrace of readers extended to inviting them into her creative process. As she was preparing to write A Lantern in Her Hand, she spoke on a radio station in Lincoln, Nebraska, about "The Pioneer in Fiction" and asked listeners to send to her "little detailed enlightening anecdotes" about the pioneer history of their own families and communities, "some dramatic thing which happened to you and which you recall vividly-or some humorous thing which still brings forth a smile as you remember." She explained that she could not pay them for material, "but ... you might have the satisfaction later of seeing it worked into a novel and you would feel that you had helped to preserve the old pioneer days in fiction." In a speech given around 1929 to a Nebraska audience, she claimed, "There had been many gracious reviews [of Lantern], but nothing any clever critic has said has meant so much to me as the commendations of the children of the prairie. No New York or Boston or London review has pleased me as have the letters from the pioneer's [sic] sons and daughters which said 'You have written the story of my own mother,' or 'Abbie Deal [the heroine of Lantern\} was just like my grandmother.'" In "Wild Critics I Have Known," published in The Bookman in 1930, she proclaimed that by "tabulat[ing]" opposing critical responses, she had ren- 
dered the critic "harmless" to her self-esteem as a writer (72). In sum, Aldrich publicly positioned herself as an ally of common readers and as a sometimes bemused spectator of professional evaluators of literature.

Aldrich's reference to readers writing her to proclaim that the fictional Abbie Deal was a realistic portrait of their mothers or grandmothers as pioneer women is literally true-scores of readers say exactly that in the nearly two hundred letters preserved in her papers. However, those letters tell only a part of the story of ordinary readers' deeply felt engagements with A Lantern in Her Hand, a kind of engagement also documented, but less extensively, in the few dozen letters to Cather that have survived. ${ }^{8}$ I turn now to documenting and theorizing the middlebrow style of reading revealed by these fan letters, reading practices that allowed a wide variety of readers from across the United States to experience a deep and sympathetic engagement with the novels' prairie pioneer heroines.

As Radway first proposed and as Jennifer Parchesky has elaborated using the evidence of readers' letters to Fisher, engagement and identification are the central dynamics of middlebrow reading. According to Parchesky, middlebrow readers sought to "assuage anxieties about a rapidly changing and deeply disconcerting modern society" by seeking "in their reading a sense of meaning and community" (232). They identified and imagined themselves as part of a community comprising both literary characters and their creators, making "a sense of identification and community among cultural producers and cultural consumers" the "hallmark of the middlebrow ethos" (233). In the reading community constructed by the BOMC, as Radway observes, literature was not conceived of as something to be "appreciated" with a sense of aesthetic distance. Instead, BOMC readers were encouraged to see literature, including novels, as something they could use (Feeling 142). As Parchesky elaborates, fiction served middlebrow readers as "structures of feeling: epistemological structures for perceiving and interpreting certain experiences as significant, and psychological, affective and narrative structures for organizing and representing their own experiences" (245). ${ }^{9}$

One of the central tropes of reader letters to both Aldrich and Cather is literary characters as friends, a trope that Cather's own father deployed. For him, the characters in Ántonia were friends in a more literal sense, fictionalized versions of his friends and family several decades ear- 
lier. Other readers of Ántonia and Lantern constructed imaginative scenarios in which the characters were "real" and lived in their imaginations even after the temporally limited act of reading had finished..$^{10} \mathrm{~A}$ mother of high-school-aged children from Vincennes, Indiana, explained to Aldrich: "Your stories are so real, so fine your characters are so alive, that I live the book as I read it. I rejoiced with Abbie, I mourned with her, I loved her and at the close of the day as her spirit went forth with 'the lantern in her hand[.]' I cried as for a precious friend" (Wiseman). A traveling Chautauqua lecturer from Indianola, Iowa, wrote to Cather that he read all of her books, including Ántonia, "slowly-leaving intervals between them -I want them to last a life time." Conflating real and fictional places and characters in central Nebraska (a practice still very common in "Catherland"), he explained, "I know your Nebraska wellI have stopped at the hotel where Ántonia worked - I heard Blind Boone play in the parlor and I have seen his watch" (Winters). Implicitly analogizing the act of reading with a social interaction with a person, a young woman from Lakewood, Ohio, wrote to Aldrich that "Abbie Deal and I have become acquainted with each other about six different times" since she first checked Lantern out of a library six years before. She described herself as "grateful" to Abbie for the example she set of self-sacrifice (as a young woman, Abbie dreams of going to New York and becoming a singer or actress, but her marriage to Will forecloses this possibility, as well as her ambitions to paint and to write). Using language very much like Fisher's BOMC recommendation of Ántonia, this twenty-year-old reader also said that it would take her a "lifetime" of rereadings to "grow up to" Aldrich's novel. At the conclusion of her very long letter, she explained clearly the way that Lantern had provided her with a "structure of feeling" that helped her meet the challenges of modernity: "If ever I feel muddled up about the turn of events in my own life, Abbie Deal always helps me see straight again. If I ever need a jolt out of a rut of taking modern life for granted, Abbie will show me all the hard work in its beginning" (Walker).

Readers extended this construction of friendship and intimacy to include others they had never met in the flesh, Aldrich and Cather. As a fifteen-year-old girl wrote to Aldrich, enclosing a photo inscribed "Your devoted friend," "It seems funny - we have never seen each other, you didn't even know I existed and yet you are one of my best friends" (Brand). A nineteen-year-old man studying at a Catholic College in rural Wisconsin characterized himself as a classic middlebrow reader, but one frustrated by Cather's lack of an orthodox religious vision. When he read, 
he explained to Cather, he sought to "penetrat[e] the story to the heart of its creator in an attempt ... to find the writer himself," seeking "companionship with another mind that lived beyond ink." Characterizing Anton Rosicky of "Neighbour Rosicky" and Ántonia as "the kind of people I would like to meet on summer evenings, walking through quiet fields to them, to look at them and listen to them," he complained that these literary friends did not bring him the "peace" he sought. He routed his frustration through an oblique reference to the most quoted passage in $M y$ Antonio, in which Jim Burden characterizes the adult Ántonia as firing his imagination with the simple gesture of putting her hand on a crabapple tree, making him "feel the goodness of planting and tending and harvesting at last" (342). Ántonia "unconsciously found" a "deep peace," the reader complained to Cather, but "it was only that of a beautiful superior plant life; and I was sorry because (selfishly?) I thought I had come to the end of my friendship with you" (Curran).

These rural and small-town Midwesterners were not the only readers to claim Cather, Aldrich, and their characters as friends, and even as "family." Letters to both authors revealed a broad geographic diversity as well as class and occupational diversity. Not just lawyers and bank presidents, but housewives, farmers, teachers, students, ministers, manual laborers, secretaries, and clerks also wrote. Furthermore, even letters that proclaimed a family connection to prairie-pioneer subject matter often testified to a Nebraska diaspora, the movement of the children and grandchildren of women like Abbie away from the region of their birth or early migration. Although Lantern culminates with the triumphant full flowering of the state of Nebraska, with Abbie Deal's life synecdochally representing the state's history, post-pioneer out-migration and depopulation were already a historical and demographic reality in the 1920s (Nugent 193, 244). Thus we find a New York lawyer born in Platte County, Nebraska, describing himself as "so much a plainsman that it was very difficult for me to read [Lantern] except with deep emotion - it is very real to me for I love the prairie country" (Matters). An older woman from Monterey, California, described her own experience homesteading near Lexington, Nebraska, in 1884, followed by a move to "the newer country-Oklahoma, but I have always felt that some part of me was left in Nebraska." Burdened with the care of a seriously disabled husband, she expressed her "unsatisfied yearning to return to my childhood home and tho I may never realize my desire, I know it will go with me to 'the End of the Chapter' unless I do." Nevertheless, she could travel to Nebraska in her imagination and take inspi- 
ration from Abbie Deal's struggles (Campbell). A professor of sociology at a theological seminary in the Philippines represented a particularly revealing case. He first described his "homesickness" for Nebraska after reading Lantern and placed his childhood and family in relation to "the Nebraska county which Willa Siebert [sic] Cather immortalized in some of her earlier books." He then described his own journey away from a childhood "on a poor Webster county farm" for education at the University of Nebraska, theological study at Yale, a brief return to Hastings, Nebraska, as a minister, but then his move half a world away. Finally, however, he protested the fact that all of Abbie Deal's children move off the farm. "I love Nebraska, and it is a matter of pride to me that my state has such writers as yourself, Cather, and Neihardt to sing its worth," he wrote, but he gently rebuked Aldrich for writing a novel in which "the kind of success the children of Abbie Deal achieved consisted ... in escape from the farm" (Fey). This sociology professor was anxious to claim Cather for Nebraska as a counterweight to this exodus, but Cather was herself a Nebraska expatriate-she lived most of her adult life in New York City. However, reading My Ántonia enabled readers from everywhere to live through the Nebraska pioneer era, whether or not they had direct experience of it.

Similarly, as Carol Miles Peterson suggests and Aldrich's fan letters confirm, Aldrich "offered to her readers the feel of the country, the best of their memories of rural homes known or imagined" (Introduction xiii). Because as middlebrow readers, they identified intensely with characters, people with no "real" connection to the pioneer era on the plains nevertheless acquired "memories" of "imagined rural homes" through reading. That is, reading about Abbie Deal's life became a means through which people from throughout the nation experienced the same affective, emotional ties to the pioneer era as those with familial connections to the pioneers. A woman from Henrietta, North Carolina, who identified herself as "just one of the plain mothers of America" who had "never known pioneer life on the prairies" still thanked Aldrich for portraying "those same heart breaking struggles [and] thoughts" she experienced as a mother (Cain). A young woman from an economically marginal family in New York wrote Aldrich at length about her and her mother's intense emotional and imaginative engagements with Aldrich's fiction, especially Lantern. After her mother finished "that epic of Nebraska," she told her daughter, "Life would never have seemed so dull if I could have known there were books like Abbie Deal's life to turn to." Writing in 1935, the daughter reported that at times "the depression spreads like a 
blanket over" the entire city of New York, and she herself felt "caught in the web that is depression" when she graduated high school and had trouble finding work. However, after reading Lantern and Aldrich's other novels, she would go to the rooftop of her building and imagine seeing the prairies or "standing in the doorway with Abbie Deal watching the sunset. "She, like many of both Aldrich's and Cather's readers, reported first discovering Aldrich's books in public libraries, but she and her mother used scarce financial resources to buy their own copies, which her mother, "who is the soul of generosity in everything, refuses to put them out where careless friends may casually borrow them. Instead, they are carefully tucked away," lent only to friends who were "booklover[s] of the first order" (Brennan).

The intense affective ties Aldrich's readers express bring us back to dismissals of Aldrich's writing as "sentimental," charges that are often oddly paired with the "optimistic" or "romantic" as negative terms in the vocabulary of Western literary history. Certainly, in Aldrich's characterizations of her motivations for writing Lantern and the relation of it to previous depictions of similar subject matter, she proclaimed her own optimism. Acknowledging her own "audacity" in writing about "midwest women of the soil" in the wake of Hamlin Garland and Ole Edvart Rolvaag, she complains, "They had so often drawn these women as gaunt, hopeless despairing creatures ... browbeaten women ... women whom life seemed to defeat at the end. That was not my mother nor the mothers" of other Nebraskans (ellipses in the original). Instead, she characterizes her mother as an optimist who did not seek the "pity" of a later generation looking back on her hardships (unfilled).

Nevertheless, Aldrich's novel is far grimmer and less optimistic than My Ántonia, which ends with Ántonia in vigorous middle age, surrounded by her healthy children and satisfied with the course her life has taken. Death, disappointment, and betrayal come early in Ántonia's life and in the novel, not at its conclusion. Lantern ends, instead, with its heroine's death after many years of loneliness and frustration because she has lost her husband's companionship to death and her adult children do not fully understand or value her. Her children succeed because of her willingly made sacrifices, but she still grieves for what she has lost. Even Abbie's role as a symbol of Nebraska's triumph as an agricultural state is far more ambiguous than it seems. As the Nebraska expatriate from the Philippines astutely pointed out, all of Abbie's children "succeed" by leaving the farm. Even more significantly, Abbie sells off her farm, piece by piece, to finance their education and even- 
tual successes, leaving her a pioneer farmwoman without a farm, just a farmhouse.

Readers wrote to Aldrich to tell her that Abbie "inspired" them, but the long time span covered by the novel (1854-1927) and the length of Abbie's life allowed readers to draw very different lessons from it. Some readers found "inspiration" in Abbie's optimism in her early life, when she refused to let obstacles and failures beat her down, but others found "inspiration" in her later life as an exemplar of self-sacrifice and of resignation in the face of frustration, age, and loss. The New York lawyer from Nebraska, for instance, wrote not just about his Nebraska childhood, but about his non-Nebraska wife's death, sending a copy of Lantern for Aldrich's autograph "because it was the last book my wife, Amy L. Matters, read before her passing. I shall always recall the great joy this story of pioneer life afforded her" (Matters). A partially paralyzed invalid from Los Angeles wrote about how reading transported her imaginatively out of her sickbed, but she also recounted to Aldrich how Lantern and its sequel A White Bird Flying (which follows the life of Abbie Deal's granddaughter Laura) "helped me to become more reconciled to the recent death of a very beloved sister" (Chessman). Twenty years after the book's first publication, a recent widow from Girth, Idaho, suggested that years of reading and thinking about Aldrich's novel had prepared her for what she confronted in the present: "All through the years I must have known it would be this way. I've cried barrels of tears over THE LANTERN IN HER HAND. I'll try to be like Abbie Deal and not be a bother to my children but the years will be long without them" (Reid). Another widow, an uneducated Russian emigrant whose husband died when her two children were young, wrote fifteen years after that death. She thanked Aldrich for Abbie's story as an example that gave her the courage to open a small business (a bookshop) in Olympia, Washington, and to make sacrifices in order to educate her children, citing in particular Abbie's example as "this fine American Pioneer type who sold parcel by parcel of her valuable land to send her children to School" (Blom).

These remarks of the early twentieth-century readers suggest that the sentimentality of Aldrich's novel worked in precisely the way that Joanne Dobson theorizes in relation to nineteenth-century literary sentimentalism. Sentimentalism is "premised on an emotional and philosophical ethos that celebrates human connection, both personal and communal, and acknowledges the shared devastation of affectional loss," Dobson claims (266). Based on this ethos, sentimental writers respond in two primary ways to the threat of "violation, actual or threatened, of affectional 
bonds": by producing either "bleak, dispirited, anguished, sometimes outraged, representations of human loss" or "idealized portrayals of human connection or divine consolation" (267). The latter half of Aldrich's novel is not outraged, but it is often bleak, and Abbie is often dispirited and anguished. Readers responded to Aldrich's representations of loss by imagining their own idealized human connections to both Abbie and her creator. Likewise, one might classify Ántonia as sentimental in the optimistic mode, because it ends with an idealized portrait of the reclaimed and reconstituted human connection between Jim and Ántonia.

In reading My Ántonia and A Lantern in Her Hand, people throughout the nation came to possess the stories of Nebraska pioneer women as a familial inheritance through the practices of middlebrow reading, which privileged deep absorption and emotional engagement and identification with characters. How is it, then, that Aldrich's and Cather's novels have maintained a devoted following among ordinary readers, remaining continuously in print, while having very different fates in terms of the literary canon based on judgments by professional readers like us? Returning to the question of how each writer positioned herself in relation to the market, I explore how, over time, two classes of readers came to diverge in their judgments. I also argue that academic readers should take a cue from ordinary readers by taking Aldrich seriously and putting $M y$ Ántonia and A Lantern in Her Hand in dialogue in literary history and the classroom.

Although My Ántonia is now canonical enough to be included in its entirety in the Norton Anthology of American Literature, literary historians did not always grant Cather such high status. O'Brien lays the blame for Cather's noncanonical status during her late career and in the decades after her death on Cather's own actions, inaction, and temperament. Cather refused, $\mathrm{O}$ 'Brien claims, to engage the "social and institutional forces that were increasingly structuring" the "writer/reader bond" in the 1930s and 1940s, turning instead for affirmation to a "view of the relationship between writer and reader" as "based on the private model of friendship" $(122,121)$. As O'Brien notes, Cather refused to allow most of her fiction to be anthologized or published in classroom editions that would allow "literary and academic institutions" to shape readers' interpretations (121). ${ }^{11}$ In her late career, I would add, she also refused opportunities to circulate her works in ways that would have made them more broadly acces- 
sible to readers outside of academic institutions. Although she allowed Armed Services Editions of My Ántonia, O, Pioneers!, and Death Comes for the Archbishop during World War II, she refused to allow a Viking Portable paperback edition of her works after the war (Chinery 293-94 ).12 And after an unhappy experience with a film adaptation of $A$ Lost Lady in 1934, she refused all further film adaptations and included provisions in her will directing her estate to do the same (Schueth).

Despite these refusals of distribution channels that would have made her works more accessible to ordinary readers, highbrow critics nevertheless tarred her with the middlebrow brush. As Jane Waterman notes, "'Best-seller," 'magazine,' 'Hollywood,' 'women's clubs,' and 'well paid' all became synonymous and encoded middlebrow terms" in the vocabulary of highbrow critics (76), and such critics deployed this arsenal of what they considered to be insults against Cather. In his review of One of Ours, for instance, Mencken complained that although the first half of One of Ours "ranks almost with My Ántonia," which he had championed, "the other [half] ... drops precipitately to the level of a serial in the Ladies Home Journal" (Schroeter 10). In 1937 in The Genteel Tradition, Lionel Trilling likewise complained that Cather's "mystical concern with pots and pans" in her "later books" was "not ... very far from the gaudy domesticity of bourgeois accumulation glorified in the Woman's Home Companion" (Schroeter 154-55). Although these critics exempted My Ántonia from their scorn, Cather's oeuvre as a whole suffered in terms of highbrow prestige.

In contrast, Aldrich's consistent public positioning of herself as a market-oriented author openly invited such dismissals. She traveled to Hollywood repeatedly, trying to interest producers in her works. She was delighted with Cheers for Miss Bishop, the 1941 adaptation of Miss Bishop (1933), and one of the great regrets of her career was that Lantern was never adapted for film (Meier 86ff). She was also enthusiastic about the Pocket Books paperback of A Lantern in Her Hand, which was printed in an edition of 275,000 copies in 1947, nearly twenty years after its first publication (Rapport) (she attempted to use the sale of the Pocket Books edition to entice Hollywood, but to no avail [Brown]). Cather's experiences as a teacher made her resist circulation of her works in formats meant for students, but Aldrich's teaching career left her with no such reservations. She embraced the use of A Lantern in Her Hand in classrooms, authorizing an educational edition and expressing pride that the novel served as supplementary reading in Nebraska high school history classrooms because of its historical accuracy ("Story Behind" ix). Tellingly, however, 
Aldrich's novel found its way into high school, not college and university, classrooms. ${ }^{13}$

So what was the source of the eventual rise of Cather's stock in the prestige economy and the accession of My Ántonia into the canon of literary texts taught at the postsecondary level? Deborah Lindsay Williams has argued that Cather's refusal to affiliate herself publicly with women authors who were her contemporaries underwrote Cather's eventual reclamation for the canon. I believe Cather's public disavowals of the popular taste just as she first hit the bestseller lists with One of Ours similarly preserved her availability for recuperation because such disavowals have encouraged critics in the past two decades to read her as a literary modernist. "The Novel Démeumblé," her screed against commercialism and the popular taste, now appears in the Norton Anthology as one of a group of "Modernist Manifestos."14 In contrast, Aldrich's avowed market orientation and her embrace of the tastes of a mass audience made it easy for academic readers to dismiss her as a sentimental hack.

As Pierre Bourdieu argues, in the field of cultural production the most prestige and cultural capital accrues to artists who position themselves as producing for the sake of art and refusing to compromise to the demands of a broad audience, while the least prestige accrues to "the "popular" that derives its "consecration" from "the choice of ordinary consumers, the "mass audience'" (51). Behind the scenes. Cather was nearly as engaged with "ordinary consumers" as Aldrich, but her seemingly unambivalent disavowals in public appealed to the values of those who evaluate literature professionally. ${ }^{15}$ Yet nonacademic readers imagined - and continue to imagine - the pioneer era through their deep attachments to Ántonia and Abbie as their "friends." What if academic readers conceive of these sentimental attachments of middlebrow readers to Cather's and Aldrich's novels as a source of value, a reason to "consecrate" both My Ántonia and A Lantern in Her Hand as meriting serious attention? Read the paeans to $A$ Lantern in Her Hand posted by readers on Amazon.com, teach it to your students, take their sentiments seriously, and perhaps dare to let your own sentiments be engaged, just as you do with Cather's pioneer fiction.

\section{Acknowledgments}

Thanks to the staff of Archives and Special Collections at the University of Nebraska-Lincoln's Love Library and of the Nebraska State Historical Society. Thanks as well to the following scholars for their help and advice and for sharing resources: Jaime Harker, Molly O’Hagan Hardy, Mark Madigan, and Vicki Martin. 


\section{Notes}

1. Sales figures are drawn from Cather's "Bank Book," in which she entered both the amount paid and sales numbers reported by publishers.

2. For typical dismissive characterizations of Aldrich as "sentimental," see Meyer $(68-9,200)$ and Western Literature Association's Literary History (652); Cather receives extended, laudatory treatment in both. Aldrich receives passing attention in broad thematic surveys (e.g., Fairbanks, Quantic, and Raub). Although I have sought out original materials, Peterson's biography was an essential guide in my research. In Updating the Literary West, the Western Literature Association notes in passing the availability of Peterson's biography and the Bison Books edition of Lantern $(644,674)$ while devoting an entire chapter to the most recent decade of Cather scholarship.

3. Because Cather's will prohibits direct quotation from her unpublished letters, I quote $\mathrm{O}^{\prime}$ Brien's paraphrase.

4. Harker foregrounds the progressive politics of her subjects, which Aldrich and Cather did not share, but she makes clear that middlebrow authorship was not exclusively progressive (20).

5. For recent analyses of Cather in women's magazines and her negotiations with editors and agents, see Bucker and Roorda. For women's magazines as middlebrow, see Harker (chap. 1).

6. On Cather's friendship with Woollcott, see Chinery (286-89). Note, however, that she mischaracterizes Cather's opposition to being drawn into Woollcott's radio program (287) - Cather objected only to her works being read aloud, not to being the subject of comment.

7. On D. Appleton's enthusiastic pursuit of BOMC main selection status for Lantern, see Jewett. Lee documents main selections for the 1920s through the 1940s, but not alternates. A review of the BOMC News located no reference to Aldrich's books.

8. It is impossible to know whether Cather actually received fewer fan letters than Aldrich, or whether she saved fewer, or Edith Lewis or Cather's family preserved fewer after her death. During her lifetime, Cather seems to have preserved more letters related to One of Ours - in a letter to Carrie Miner Sherwood, Lewis describes letters from soldiers about One of Ours as having filled "one small suitcase" while Cather discarded other letters. Furthermore, in her memoir of Cather, Lewis briefly quotes from a number of reader letters including letters about Ántonia that do not survive (186-88). Likewise, clearly only a fraction of Aldrich's reader letters survive. Many letters reference earlier letters not extant, for instance. In June 2008, too late to be included in this study, more than seventy-five previously unknown fan letters to Cather were donated to the Susan J. Rosowski Collection at the University of NebraskaLincoln Archives and Special Collections. 
9. Both Radway and Parchesky conceive of middlebrow readers in narrow class terms - for Radway, the professional managerial class (such as Cather's bank president brother Roscoe), for Parchesky the new middle class (especially teachers). Reader letters to Aldrich suggest that people from a much broader range of class positions employed middlebrow reading practices.

10. See Greer for the deployment of this same trope by working class women who studied in Bryn Mawr College's summer program, as well as the nineteenthcentury precedents for it. See also Ryan for fan letters to Gene Stratton Porter, another regional novelist with devoted readers.

11. O'Brien also depicts Cather as "refus[ing] to allow her books to be adopted by book clubs" as part of her resistance to any force that would "force" readers to read her books $(122,121)$. However, Madigan's recovery of the range of Cather's engagements with the BOMC complicates this picture. I would also add that Rubin's and Radway's work on the BOMC and the middlebrow sharply distinguishes the judgments of middlebrow cultural authorities from academic ones.

12. As Chinery notes, this edition likely led to hundreds of fan letters to Cather about Ántonia that have not survived (293).

13. Dorothy Canfield Fisher and Pearl Buck shared the same fate, transformed into "adolescent literature" and "K-12 staples" (Harker 152).

14. Modernist antagonism toward mass culture has spawned a vast scholarly literature. See Botshon and Goldsmith for a summary and the implications for the middlebrow.

15. Even in private, Cather evidenced some ambivalence about popularity. Writing to her brother, she simultaneously embraced and distanced herself from her own popularity, saying that she didn't think a really good writer could be popular in his own lifetime.

\section{Works Cited}

Aldrich, Bess Streeter. "How I Mixed Stories with Doughnuts." In Collected Short Works, 1920-1954, edited by Carol Miles Peterson, 33-4:2. Lincoln: University of Nebraska Press, 1999.

—_. A Lantern in Her Hand. 1928. Lincoln: University of Nebraska Press, 1994.

. [The Pioneer in Fiction]. Ts of radio address, 1925. Aldrich Papers.

. "The Story Behind A Lantern in Her Hand." 1952. In A Lantern in Her Hand, v-x.

—. Untitled. "Nebraska History in Nebraska Novels." Transcript draft of speech, ca. 1929. Aldrich Papers.

- Untitled. Transcript draft of speech to Nebraska Writers Guild [?], ca. 1931. Aldrich papers. 
—. "Wild Critics I Have Known." Bookman November 1930: 72-73.

Blom, Anna. Letter to BSA. 19 May 1943.

Bloom, Sarah J. [Willa Cather's secretary]. Letter to Roscoe Cather. [14 Mar. 1935]. R\&M Cather.

Botshon, Lisa, and Meredith Goldsmith. "Introduction." In Middlebrow Moderns: Popular American Women Writers of the 1920s, edited by Lisa Botshon and Meredith Goldsmith, 3-21. Boston: Northeastern University Press, 2003.

Bourdieu, Pierre. The Field of Cultural Production: Essays on Art and Literature. Edited by Ronald Johnson. New York: Columbia University Press, 1993.

Brand, Thelma Taby. Letter to BSA. n.d. [after 1935].

Brennan, Mary. Letter to BSA. 10 November 1935.

Brown, Ned. Letter to BSA. 11 September 1947.

Bucker, Park. "'That Kitchen with the Shining Windows': Willa Cather's 'Neighbour Rosicky' and the Woman's Home Companion." In Willa Cather E Material Culture: Real-World Writing, Writing the Real World, edited by Janis P. Stout, 66112. Tuscaloosa: University of Alabama Press, 2005.

Cain, Mrs. Charles. Letter to BSA. 30 January 1935.

Campbell, Lola A. Letter to BSA. 18 March 1935.

Cather, Charles. Letter to WC (fragment). [1918]. Southwick.

Cather, Willa. Bank Book 1913-30. Rosowski.

— . Letter to Roscoe Cather. 8 December [1918]. R \& M Cather.

- Letter to Roscoe Cather. 11 January [1934]. R \& M Cather.

. My Ántonia. 1918. Willa Cather Scholarly Edition. Lincoln: University of Nebraska Press, 1994.

—_. "The Novel Démeumblé." Not Under Forty. New York: Knopf, 1936.

Chessman, Hallie L. Letter to BSA. 16 January 1935.

Chinery, Mary. "Wartime Fictions: Willa Cather, the Armed Services Editions, and the Unspeakable Second World War." In Cather Studies: History, Memory, and War, edited by Steven Trout, 285-96. Lincoln: University of Nebraska Press, 2006.

Curran, John. Letter to WC. 18 February 1936. Rosowski.

Dobson, Joanne. "Reclaiming Sentimental Literature." American Literature 69.2 (1997): 263-88.

Fairbanks, Carol. Prairie Women: Images in American and Canadian Fiction. New Haven, CT: Yale University Press, 1986.

Fey, Harold E. Letter to BSA. 27 April 1931.

Greenslet, Ferris. Letter to WC. 27 October 1921. Rosowski.

Greer, Jane. "'Ornaments, Tools, or Friends': Literary Reading at the Bryn Mawr Summer School for Women Workers, 1921-1938." In Ryan and Thomas. 179-98.

Harker, Jaime. America the Middlebrow: Women's Novels, Progressivism, and Middlebrow Authorship Between the Wars. Amherst: University of Massachusetts Press, 2007.

Knight, Denise D. "'I Try to Make the Reader Feel': The Resurrection of Bess Streeter Aldrich's A Lantern in Her Hand and the Politics of the Literary 
Canon." In Separate Spheres No More: Gender Convergence in American Literature, 1830-1930, edited by Monika M. Elbert, 282-96. Tuscaloosa: University of Alabama Press, 2000.

Lee, Charles. The Hidden Public: The Story of the Book-of-the-Month Club. New York: Doubleday, 1958.

Lewis, Edith. Letter to Carrie Miner Sherwood. 19 December [195-]. Willa Cather Foundation, Red Cloud, NE.

- Willa Cather Living: A Personal Record. New York: Knopf, 1953.

Madigan, Mark. "Willa Cather and the Book-of-the-Month Club." In Cather Studies: Willa Cather as Cultural Icon, edited by Guy Reynolds, 68-85. Lincoln: University of Nebraska Press, 2007.

Matters, Thomas H., Jr. Letter to BSA. 6 April 1935.

Meier, A. Mabel. “Bess Streeter Aldrich: A Literary Portrait." Nebraska History 50.1 (1969): 66-100.

Meyer, Roy W. The Middle Western Farm Novel in the Twentieth Century. Lincoln: University of Nebraska Press, 1965.

Nugent, Walter. Into the West: The Story of Its People. New York: Vintage, 1999.

O'Brien, Sharon. "Becoming Noncanonical: The Case against Willa Cather." American Quarterly 40.1 (1988): 110-26.

Parchesky, Jennifer. “'You Makes Us Articulate': Reading, Education, and Community in Dorothy Canfield's Middlebrow America." In Ryan and Thomas. 229-58.

Peterson, Carol Miles. Bess Streeter Aldrich: The Dreams Are Real. Lincoln: University of Nebraska Press, 1995.

- . "Introduction." The Collected Short Works, 1907-1919, edited by Bess Streeter Aldrich, vii-xiv. Lincoln: University of Nebraska Press, 1995.

Quantic, Diane Dufva. The Nature of Place: A Study of Great Plains Fiction. Lincoln: University of Nebraska Press, 1995.

Radway, Janice A. A Feeling for Books: The Book-of-the-Month Club, Literary Taste, and Middle-Class Desire. Chapel Hill: University of North Carolina Press, 1997.

_ . "Research Universities, Periodical Publication, and the Circulation of Professional Expertise: On the Significance of Middlebrow Authority." Critical Inquiry 31.1 (2004): 203-28.

Rapport, Samuel. Letter to BSA. 3 September 1947.

Raub, Patricia. Yesterday's Stories: Popular Women's Novels of the Twenties and Thirties. Westport, CT: Greenwood, 1994.

Reid, Agnes Just. Letter to BSA. 7 December 1947.

Roorda, Rebecca. "Willa Cather in the Magazines: 'The Business of Art." Willa Cather Newsletter \& Review 44.3 (2001): 71-75.

Rubin, Joan Shelley. The Making of Middlebrow Culture. Chapel Hill: University of North Carolina Press, 1992.

Ryan, Barbara. "'A Real Basis from Which to Judge': Fan Mail to Gene StrattonPorter." In Ryan and Thomas. 161-78.

Ryan, Barbara, and Amy Thomas, eds. Reading Acts: U.S. Readers' Interactions with Literature, 1800 - 1950. Knoxville: University of Tennessee Press, 2002. 
Schroeter, James, ed. Willa Cather and Her Critics. Ithaca: Cornell University Press, 1967.

Schueth, Michael. "Taking Liberties: Willa Cather and the 1934 Film Adaptation of A Lost Lady." In Willa Cather and Material Culture: Real-World Writing, Writing the Real World, edited by Janis P. Stout, 113-24. Tuscaloosa: University of Alabama Press, 2005.

Walker, Vivian. Letter to BSA. 10 February 1937.

Waterman, Jayne. "Louis Bromfield and the Idea of the Middle." Midamerica: The Yearbook for the Study of Midwestern Literature 30 (2003): 73-84.

Western Literature Association. A Literary History of the American West. Forth Worth: Texas Christian University Press, 1987.

- Updating the Literary West. Forth Worth: Texas Christian University Press, 1997.

Williams, Deborah Lindsay. Not in Sisterhood: Edith Wharton, Willa Cather, Zona Gale, and the Politics of Female Authorship. New York: Palgrave Macmillan. 2001.

Williams, J. L. B. Letters to BSA. 5 November 1928 and 25 January 1929.

Winters, Emerson. Letter to WC. 2 November 1940. Southwick.

Wiseman, Mrs. Arthur. Letter to BSA. [1936].

In citations for letters, Willa Cather as recipient is abbreviated as WC and Bess Streeter Aldrich as BSA. All letters to Bess Streeter Aldrich are from the Bess Streeter Aldrich Papers, Nebraska State Historical Society Library, Lincoln, NE. The following abbreviations are used for other archival collections, all at the University of Nebraska-Lincoln Archives and Special Collections:

R \& M Cather: $\quad$ Roscoe and Meta Cather Collection

Rosowski: James R. and Susan J. Rosowski Collection

Southwick: $\quad$ Philip L. and Helen Cather Southwick Collection 